\begin{tabular}{lllllllllllllllll}
$\mathrm{S}$ & $\mathrm{T}$ & $\mathrm{U}$ & $\mathrm{D}$ & $\mathrm{I}$ & $\mathrm{A}$ & & $\mathrm{T}$ & $\mathrm{E}$ & $\mathrm{M}$ & $\mathrm{A}$ & $\mathrm{T}$ & $\mathrm{Y}$ & $\mathrm{C}$ & $\mathrm{Z}$ & $\mathrm{N}$ & $\mathrm{E}$ \\
\hline
\end{tabular}

STUDIA Z PRAWA WYZNANIOWEGO

Tom $21-2018$

DOI: https://doi.org/10.31743/spw.192

ANNA TUNIA*

\title{
DUCHOWNY JAKO PODMIOT ADMINISTRUJĄCY W SPRAWACH Z ZAKRESU ADMINISTRACJI STANU CYWILNEGO
}

\author{
Streszczenie
}

Przedmiotem artykułu jest ukazanie charakteru i katalogu zadań wykonywanych przez podmioty należące do kościołów i innych związków wyznaniowych w zakresie administracji stanu cywilnego. W związku z tym w pierwszej części artykułu wyjaśnione zostały podstawowe pojęcia stosowane w publikacji, a następnie wskazany został krąg podmiotów administrujących w systemie administracji stanu cywilnego. Dokonana została analiza zadań, jakie realizowane są przez podmioty wyznaniowe (duchownych) jako podmioty wykonujące określone zadania z zakresu administracji stanu cywilnego. Zadania te sprowadzają się do wykonywania określonych czynności związanych z zawarciem i rejestracją małżeństwa w trybie określonym w kodeksie rodzinnym i opiekuńczym. Są to zadania wykonywane w sytuacjach zwyczajnych oraz w przypadkach nadzwyczajnych tj. w razie niebezpieczeństwa grożącego bezpośrednio życiu jednej ze stron zawierających małżeństwo. W konkluzji rozważań stwierdzono, że funkcje, jakie w toku procedury zawarcia małżeństwa w trybie art. 1 $\S 2$ k.r.o. sprawuje duchowny mają charakter zadań zleconych z zakresu administracji publicznej. Podstawę do ich wykonania stanowią odpowiednie przepisy prawa państwowego. W toku tych czynności duchowny działa nie we własnym imieniu, ale jako organ osoby prawnej, którą jest określona jednostka organizacyjna kościoła lub innego związku wyznaniowego (np. parafia). Wykonując te czynności duchowny jest podmiotem administrującym, który realizuje tę funkcję $\mathrm{w}$ imieniu kościoła lub innego związku wyznaniowego uprawnionego do stosowania wyznaniowej formy zawarcia małżeństwa na podstawie odpowiednich przepisów prawa.

* Dr hab., prof. KUL, Katedra Prawa Technologii Informacyjnych i Komunikacyjnych, Wydział Prawa, Prawa Kanonicznego i Administracji, Katolicki Uniwersytet Lubelski Jana Pawła II, Al. Racławickie 14, 20-950 Lublin, e-mail: atunia@kul.pl. ORCID 00000002-7703-0828. 
Słowa kluczowe: administracja publiczna; administracja stanu cywilnego; podmiot administrujący; małżeństwo; duchowny; kościoły i związki wyznaniowe

$* * * * *$

\section{UWAGI WSTĘPNE}

W świetle obowiązujących przepisów prawnych wykonywanie władzy publicznej w Rzeczypospolitej Polskiej należy nie tylko do organów administracji państwowej i rządowej oraz organów samorządu terytorialnego ${ }^{1}$, ale także może zostać powierzone organizacjom społecznym oraz - w wąskim zakresie - podmiotom prywatnym. Zjawisko to określane jest w nauce prawa administracyjnego jako prywatyzacja zadań publicznych ${ }^{2}$. Oznacza ono zmianę podmiotu wykonującego zadania publiczne, jednakże w razie takiej zmiany na organach państwowych nadal spoczywa odpowiedzialność za wykonanie powierzonego zadania ${ }^{3}$.

Zadania publiczne z zakresu administracji stanu cywilnego są zadaniami należącymi do administracji rządowej zleconymi jednostkom samorządu terytorialnego na mocy ustawy z dnia 17 maja 1990 r. o podziale zadań $i$ kompetencji określonych $w$ ustawach szczególnych pomiędzy organami gminy a organami administracji rzadowej i zmianie niektórych ustaw ${ }^{4}$. Należą one do właściwości organów gminy, która - zgodnie z art. 6 ust. 2 p.a.s.c. - stanowi podstawowy okręg rejestracji stanu cywilnego ${ }^{5}$. Wykonywanie zadań z zakresu administracji stanu cywilnego ma jednak charakter nietypowy. Wynika on z prywatyzowanego rodzaju tych zadań publicznych, podmiotu przejmującego ich wykonanie oraz form prywatyzacji ${ }^{6}$.

1 Zob. art. 4, 10, 16 ust. 2, 146 i 163 Konstytucji Rzeczypospolitej Polskiej z dnia 2 kwietnia 1997 r. (Dz. U. Nr 78, poz. 483 z późn. zm.). Zob. też: Garlicki, Zubik, Derlatka, Działocha, Sarnecki, Sokolewicz, Trzciński i Wiącek 2016; Skrzydło 2013.

2 Zob. Boć 2005, 175-185.

3 Zob. Biernat 1993, 6-27.

4 Dz. U. Nr 34, poz. 198 z późn. zm.

5 Ustawa z dnia 28 listopada 2014 r. - Prawo o aktach stanu cywilnego (Dz. U. z 2014 r., poz. 1741 z późn. zm.), dalej: p.a.s.c.

6 Zob. Szadok-Bratuń 2012, 205. 
Wśród podmiotów prywatnych uprawnionych do wykonywania zadań publicznych z zakresu administracji stanu cywilnego wyróżnia się m.in. kościoły i inne związki wyznaniowe. Ich udział w wykonywaniu tych zadań warunkowany jest jednak istnieniem wyraźnego przepisu prawnego „zlecającego" im ich realizację, a więc określającego wyraźnie podmiot uprawniony do ich wykonania, zakres tych zadań oraz sposób ich realizacji. W sprawach administracji stanu cywilnego podmiotem tym jest duchowny działający jako przedstawiciel kościoła lub innego związku wyznaniowego uprawnionego do procedowania przy zawieraniu małżeństw cywilnych w formie wyznaniowej.

Celem niniejszego artykułu będzie ukazanie charakteru oraz katalogu zadań wykonywanych przez podmioty należące do kościołów i innych związków wyznaniowych z zakresu administracji stanu cywilnego, które podejmowane są $\mathrm{w}$ związku z zawieraniem i rejestracją małżeństw na podstawie art. $1 \S 2$ k.r.o. ${ }^{7}$

\section{ADMINISTRACJA STANU CYWILNEGO}

Ukazanie pozycji podmiotów wyznaniowych (duchownych) jako podmiotów administrujących $\mathrm{w}$ sprawach $\mathrm{z}$ zakresu administracji stanu cywilnego wymaga wpierw wyjaśnienia samego pojęcia ,administracja stanu cywilnego”. Określenie to - tak jak pojęcie „administracja publiczna” może być rozumiane w znaczeniu podmiotowym i przedmiotowym. Administracja stanu cywilnego w znaczeniu podmiotowym (organizacyjnym) oznacza krąg podmiotów zajmujących się rejestracją stanu cywilnego. Natomiast w znaczeniu przedmiotowym (funkcjonalnym) jest to zespół zadań i kompetencji spoczywających na organach i innych podmiotach wykonujących zadania w zakresie rejestracji stanu cywilnego.

Rejestracją stanu cywilnego jest z kolei zespół czynności, których celem jest dokonanie wpisu w rejestrze stanu cywilnego w formie aktów stanu cywilnego, tj. aktu urodzenia, małżeństwa lub zgonu ${ }^{8}$. Rejestracja

7 Ustawa z dnia 25 lutego 1964 r. - Kodeks rodzinny i opiekuńczy (tekst jedn. Dz. U. z 2012 r., poz. 788 z późn. zm.), dalej: k.r.o.

8 Zob. art. 2 ust. 5 p.a.s.c. Aktom tym ustawodawca przypisuje szczególną moc dowodową, gdyż stanowią one wyłączny dowód zdarzeń w nich stwierdzonych. 
stanu cywilnego obejmuje zatem dokumentowanie trzech zdarzeń mających wpływ na stan cywilny osoby fizycznej, tj.: urodzenie, zawarcie małżeństwa i zgon, jak też dokumentowanie zmian, które występują po sporządzeniu tych aktów, mających wpływ na ich treść oraz stan cywilny osoby, której dany akt dotyczy, a także na dokonywaniu innych czynności prawnych i materialno-technicznych mających wpływ na stan cywilny osoby fizycznej ${ }^{9}$.

\section{PODMIOTY ADMINISTRUJĄCE W SYSTEMIE ADMINISTRACJI STANU CYWILNEGO}

Obejmujący podmiotowe rozumienie ,administracji stanu cywilnego" krąg organów i innych podmiotów kompetentnych do dokonywania czynności w zakresie rejestracji stanu cywilnego składa się na strukturę tej administracji. Podmiotami należącymi do systemu tej administracji są podmioty posiadające kompetencje administrowania w zakresie spraw dotyczących stanu cywilnego osób fizycznych. Zachodzi zatem potrzeba wyjaśnienia pojęcia ,podmiotu administrującego”.

Najogólniej mówiąc ,podmioty administrujące” to organy i inne podmioty, którym prawo przyznaje funkcje administrowania. Podmiotami administrującymi są przede wszystkim organy administracji publicznej, a także inne podmioty (jednostki) powołane w celu realizowania norm prawa administracyjnego, działające na podstawie i w granicach prawa ${ }^{10}$. Podstawą działania podmiotu administrującego jest zatem wyraźne upoważnienie ustawowe wyznaczające zakres jego kompetencji rozumianych jako zdolność podmiotu do wykonywania - w drodze odpowiedniego postępowania - obowiązków i praw nałożonych na niego przez prawo ${ }^{11}$.

9 Pojęcie ,stanu cywilnego" zostało obecnie zdefiniowane przez nową ustawę p.a.s.c. z 2014 r. Zgodnie z art. 2 ust. 1 tej ustawy stan ten rozumiany jest jako sytuacja prawna osoby wyrażona przez cechy indywidualizujące tę osobę, która kształtowana jest przez zdarzenia naturalne, czynności prawne, orzeczenia sądów lub decyzje organów, i stwierdzona w akcie stanu cywilnego. Szerzej na ten temat zob. Basior, Czajkowska, Sorbian 2015, 26-30.

10 Zob. Wrzosek 2013, 279-280.

11 Zob. też: Boć 1998, 119. 
Podstawy prawne i zakres działania podmiotów administrujących w systemie administracji stanu cywilnego ujęte są w przepisach ustawy Prawo o aktach stanu cywilnego, a także przepisach kodeksu rodzinnego i opiekuńczego, prawa prywatnego międzynarodowego ${ }^{12}$, prawa konsularnego ${ }^{13}$, a także w zakresie nieunormowanym w wymienionych aktach - przepisach kodeksu cywilnego ${ }^{14}$, kodeksu postępowania administracyjnego ${ }^{15}$ oraz kodeksu postępowania cywilnego ${ }^{16}$ odnoszących się do spraw związanych z rejestracją stanu cywilnego ${ }^{17}$.

W strukturze administracji stanu cywilnego możemy mówić o kilku podmiotach administrujących, którym ustawodawca przyznaje określone uprawnienia w zakresie rejestracji stanu cywilnego. Przede wszystkim należy tu wyróżnić kierownika u.s.c. (oraz jego zastępcę), który jest organem właściwym w sprawach rejestracji stanu cywilnego, tj. uprawnionym do dokonywania wpisów w rejestrze stanu cywilnego, a także wykonywania innych czynności dotyczących stanu cywilnego osób fizycznych. Kierownikiem u.s.c. z mocy prawa jest wójt, (burmistrz lub prezydent miasta), jednakże ustawodawca przewiduje możliwość zatrudnienia na stanowisku kierownika u.s.c. oraz zastępcy kierownika u.s.c. innej osoby ${ }^{18}$.

Kompetencje kierownika u.s.c. w sprawach stanu cywilnego określają wyraźnie przepisy prawa o aktach stanu cywilnego, kodeksu rodzinne-

12 Ustawa z dnia 4 lutego 2011 r. - Prawo prywatne międzynarodowe (Dz. U. Nr 80, poz. 432 z późn. zm.).

13 Ustawa z dnia 25 czerwca 2015 r. - Prawo konsularne (Dz. U. z 2015 r., poz. 1274 z późn. zm.).

14 Ustawa z dnia 23 kwietnia 1964 r. - Kodeks cywilny (tekst jedn. Dz. U. z 2017 r., poz. 459 z późn.zm.).

15 Ustawa z dnia 20 czerwca 1960 r. - Kodeks postępowania administracyjnego (tekst jedn. Dz. U. z 2017 r., poz. 1257 z późn. zm.).

16 Ustawa z dnia 17 listopada 1964 r. - Kodeks postępowania cywilnego (tekst jedn. Dz. U. z 2016 r., poz. 1822 z późn. zm.).

17 Por. Czajkowska, Pachniewska 2005, 18.

18 Zgodnie z art. 6 ust. 4 i 5 p.a.s.c. w okręgach liczących powyżej 50.000 mieszkańców wójt (burmistrz, prezydent miasta) obowiązany jest zatrudnić inną osobę na stanowisku kierownika u.s.c. oraz może zatrudnić jego zastępcę lub zastępców. Natomiast w okręgach liczących poniżej 50.000 mieszkańców wójt (burmistrz, prezydent miasta) obowiązany jest zatrudnić zastępcę kierownika u.s.c. oraz może zatrudnić inną osobę na stanowisku kierownika u.s.c. 
go i opiekuńczego oraz innych wymienionych wyżej ustaw. Podmiot ten jest uprawniony m.in. do: sporządzania aktów stanu cywilnego (urodzeń, małżeństw i zgonów), adnotacji ${ }^{19}$, przypisków ${ }^{20}$ oraz wzmianek dodatkowych $^{21}$ dołączanych do aktu stanu cywilnego na podstawie decyzji administracyjnych lub orzeczeń sądowych, do przyjmowania m.in. oświadczeń o wstąpieniu w związek małżeński, oświadczeń o wyborze nazwiska lub o powrocie do nazwiska noszonego przed zawarciem małżeństwa, jak też oświadczeń o uznaniu dziecka przez ojca, czy wydawania decyzji o zmianie imion i nazwisk. Kierownik u.s.c. dokonuje również innych czynności nie mających wpływu na stan cywilny osób, ale mających znaczenie dla treści aktów stanu cywilnego ${ }^{22}$.

Prawa i obowiązki określone przez ustawodawcę w zakresie rejestracji stanu cywilnego na równi przysługują - i są wykonywane - przez kierownika u.s.c. jak i jego zastępcę. Przyjmując taką regułę ustawodawca wyeliminował wszelkie wątpliwości interpretacyjne dotyczące zakresu merytorycznych i formalnoprawnych kompetencji zastępcy kierownika urzędu stanu cywilnego.

W strukturze administracji stanu cywilnego wyróżnić można również wojewodę, który jest organem nadzoru nad działaniami kierownika u.s.c. w zakresie rejestracji stanu cywilnego (organ nadzoru $\mathrm{I}^{\circ}$ ), jak też organem odwoławczym od decyzji administracyjnych z zakresu rejestracji stanu cywilnego wydawanych przez kierownika u.s.c. Wyróżnić można również ministra właściwego do spraw wewnętrznych (MSWiA), który jest organem nadzoru nad działalnością wojewody w zakresie rejestracji stanu cywilnego

19 Adnotacja to notatka urzędowa zawierająca informacje o okolicznościach i podstawie rejestracji urodzenia, małżeństwa albo zgonu (art. 23 p.a.s.c.), np. adnotacje, że dziecko urodziło się martwe, o ustaniu małżeństwa, jego unieważnieniu, ustaleniu nieistnienia małżeństwa, separacji.

20 Przypiski to informacje o innych aktach stanu cywilnego dotyczących tej samej osoby oraz informacje wpływające na stan cywilny danej osoby (art. 25 p.a.s.c), np. wpisywanie w akcie urodzenia informacji dotyczących zawarcia małżeństwa, rozwiązania lub unieważnienia małżeństwa lub informacji o zgonie.

21 Wzmianka dodatkowa to wpis wpływający na treść lub ważność aktu stanu cywilnego (art. 24 p.a.s.c.). Z chwilą wpisania jej do aktu stanu cywilnego staje się ona integralną częścią aktu stanu cywilnego, np. wpis o rozwodzie lub separacji, ustaleniu ojcostwa, przysposobieniu.

22 Szerzej: Czajkowska, Pachniewska 2005, 18-19. 
(organ nadzoru $\left.\mathrm{II}^{0}\right)^{23}$ oraz ministra właściwego do spraw cyfryzacji (MC), który jest organem prowadzącym elektroniczny rejestr stanu cywilnego.

Wśród podmiotów wykonujących zadania z zakresu administracji stanu cywilnego wyróżnić ponadto należy konsula, który jako organ administrujący jest uprawniony do dokonywania określonych czynności mających wpływ na stan cywilny obywateli polskich przebywających za granicą. Konsul jest uprawniony m.in. do: przyjęcia oświadczeń o wstąpieniu w związek małżeński oraz oświadczeń w sprawie nazwiska małżonków i ich dzieci, wydawania zaświadczenia stwierdzającego, że zgodnie z prawem polskim można zawrzeć małżeństwo, przyjmowania wniosków o rejestrację urodzenia lub zgonu, jeżeli urodzenie lub zgon nastąpiły za granicą i nie zostały tam zarejestrowane, czy też przyjmowania oświadczeń koniecznych do uznania ojcostwa ${ }^{24}$.

Podmiotem administrującym w sprawach z zakresu administracji stanu cywilnego jest również duchowny jako przedstawiciel kościoła lub innego związku wyznaniowego uprawnionego do wykonywania określonych zadań publicznych zleconych mu przez prawo państwowe. Podmioty wyznaniowe nie należą jednak do organów administracji publicznej w znaczeniu ustrojowym (podmiotowym, organizacyjnym), a jedynie w znaczeniu funkcjonalnym (przedmiotowym), ponieważ ich byt prawny nie jest regulowany przez przepisy prawa państwowego, ale prawa wewnętrznego danego związku wyznaniowego ${ }^{25}$. Podmioty te uzyskują status podmiotu realizującego funkcje administracji publicznej na podstawie specjalnego upoważnienia ustawowego. Nie chodzi jednak przy tym o „oddanie” tym podmiotom prawa do wydawania decyzji administracyjnych, ale o powierzenie im określonych zadań realizowanych na płaszczyźnie zadań publicznych ${ }^{26}$. Chodzi tu o zadania publiczne realizowane w związku z zawieraniem mał-

23 Sprawowanie nadzoru przez ministra polega w szczególności na: 1) przeprowadzaniu kontroli, w tym na badaniu: prawidłowości prowadzonych przez wojewodę postępowań administracyjnych, oraz terminowości załatwiania spraw z zakresu rejestracji stanu cywilnego; 2) kształtowaniu jednolitej polityki w zakresie rejestracji stanu cywilnego i kontroli wykonywania ustalonych sposobów postępowania.

24 Uprawnienia te wynikają głównie z przepisów art. 34 pkt 11-16 ustawy - Prawo konsularne oraz art. $1 \S 4$ kodeksu rodzinnego i opiekuńczego.

25 Zob. Góralski 2007, 5.

26 Zob. Boć 2005, 185-186. 
żeństw cywilnych w formie wyznaniowej, przekazane tym podmiotom na podstawie odpowiedniego upoważnienia zawartego w ustawie.

\section{ZADANIA DUCHOWNEGO Z ZAKRESU ADMINISTRACJI STANU CYWILNEGO}

Jak wspomniano wyżej, krąg zadań realizowanych przez administrację stanu cywilnego obejmuje trzy kategorie spraw z zakresu rejestracji zdarzeń cywilnych, jakimi są: urodzenie, zawarcie małżeństwa oraz zgon. Zadania duchownego w sprawach administracji stanu cywilnego sprowadzają się do obowiązków wykonywanych w związku z zawieraniem małżeństw w formie wyznaniowej. $Z$ chwilą bowiem wejścia w życie przepisów wprowadzających religijną formę zawarcia małżeństwa cywilnego ${ }^{27}$ część kompetencji realizowanych $\mathrm{w}$ procedurze rejestracji małżeństw zawieranych $\mathrm{w}$ tej formie, przejęły podmioty wyznaniowe należące do uprawnionych związków wyznaniowych. Kompetencje te wynikają wprost z ustawy, a podmiotem wykonującym (administrującym) zadania $\mathrm{z}$ tego zakresu jest uprawniony duchowny ${ }^{28}$. Podstawę do wykonywania przez niego określonych obowiązków stanowi upoważnienie ustawowe zawarte w przepisach kodeksu rodzinnego i opiekuńczego oraz w ustawie - Prawo o aktach stanu cywilnego. Ponadto w odniesieniu do małżeństw zawieranych w Kościele katolickim są to także przepisy konkordatu z $1993 \mathrm{r}^{29}$

W nauce prawa wyznaniowego pozycja prawna duchownego jako podmiotu administrującego $\mathrm{w}$ sprawach dotyczących zawarcia i rejestracji małżeństwa na podstawie art. $1 \S 2$ k.r.o. jest wyjaśniana dość zbieżnie. Wskazuje się m.in., iż duchowny jako przedstawiciel kościoła lub innego związku wyznaniowego uprawnionego do stosowania wyznaniowej formy zawarcia małżeństwa, jest podmiotem prywatnym, któremu prawo polskie zleca w tej procedurze określone funkcje należące do sfery administracji publicznej (podmiot administrujący) ${ }^{30}$. Stwierdza się też, że

27 Tj. od 15 listopada $1998 \mathrm{r}$.

28 Zob. Tunia 2015, 188-189.

29 Zob. Konkordat między Stolicą Apostolską i Rzecząpospolitą Polską podpisany w dniu 28 lipca 1993 r. (Dz. U. Nr 51, poz. 318). Szerzej zob. Tunia 2008, 34.

30 Zob. Góralski 2007, 346-350; Góralski 2005, 129-130. 
duchowny ten jest funkcjonariuszem publicznym, wykonującym określone zadania $\mathrm{w}$ procedurze zawarcia małżeństwa w formie wyznaniowej przyznane mu przez ustawodawcę państwowego ${ }^{31}$, bądź też bardziej lapidarnie, iż duchowny pełni w toku tej procedury „niejako rolę urzędnika państwowego"32. Powyższe rozumienie tego podmiotu skonfrontować można z poglądami włoskiej nauki prawa wyznaniowego, gdzie dość powszechnie uważa się, iż duchowny sprawujący funkcje kultowe, wobec którego zawierane jest małżeństwo cywilne w formie wyznaniowej, wykonuje nie tylko funkcje publiczne, lecz posiada - w tym zakresie - pozycję urzędnika publicznego ${ }^{33}$.

Należy jednak zauważyć, że katalog zadań duchownego wykonywanych w związku z zawieraniem małżeństwa różnicuje się w zależności od okoliczności, w których jest ono zawierane. Chodzi tu o zadania realizowane w sytuacji zwyczajnej zawierania małżeństwa, tj. gdy stronom nie zagraża bezpośrednie niebezpieczeństwo śmierci oraz w przypadku nadzwyczajnym (in periculo mortis), o którym mowa w art. $9 \S 2$ k.r.o.

\subsection{ZADANIA WYKONYWANE W SYTUACJACH ZWYCZAJNYCH}

Kompetencje duchownego, obejmujące zespół zadań, praw i obowiązków realizowanych w procedurze zawierania małżeństwa cywilnego w formie wyznaniowej w sytuacji zwyczajnej, sprowadzają się do kilku czynności, które polegają na:

- przyjęciu zaświadczenia kierownika u.s.c. o braku między stronami okoliczności wyłączających zawarcie małżeństwa, o którym mowa w art. $4^{1} \S 1$ k.r.o. (art. $8 \S 1$ k.r.o.);

- przyjęciu oświadczeń woli jednoczesnego zawarcia małżeństwa podlegającego prawu polskiemu, o którym mowa w art. $1 \S 2$ k.r.o. (art. 8 § 1 k.r.o.);

- sporządzeniu zaświadczenia stwierdzającego złożenie oświadczeń przewidzianych w art. $1 \S 2$ k.r.o. (art. $8 \S 2$ k.r.o.);

\footnotetext{
31 Zob. Rakoczy 2014, 164-165.

32 Zob. Osuchowska 2010, 125.

33 Zob. Stanisz 2007, 242.
} 
- przekazaniu zaświadczenia, o którym mowa w art. $8 \S 2$ k.r.o. do urzędu stanu cywilnego (art. 8 § 3 k.r.o.) $)^{34}$.

Duchowny nie ma zaś obecnie obowiązku dokonywania pouczenia nupturientów o treści podstawowych przepisów prawa polskiego dotyczących małżeństwa i jego skutków, który wynikał z art. 62a poprzednio obowiązującej ustawy z dnia 28 września 1986 r. - Prawo o aktach stanu cywilnego ${ }^{35}$.

Spośród wymienionych zadań duchownego jedno z nich, tj. przyjęcie oświadczeń woli jednoczesnego zawarcia małżeństwa podlegającego prawu polskiemu, o których mowa w art. $1 \S 2$ k.r.o. należy do funkcji, które w procedurze cywilnej realizuje kierownik u.s.c. Pozostałe zaś wymogi wynikają ze specyfiki wyznaniowej formy zawarcia małżeństwa ${ }^{36}$.

\subsubsection{PRZYJĘCIE ZAŚWIADCZENIA, O KTÓRYM MOWA W ART. $4^{1} \S 1$ K.R.O.}

Zgodnie z art. $4^{1} \S 1$ k.r.o. osobom zamierzającym zawrzeć małżeństwo w sposób określony w art. 1 § 2 i 3 k.r.o. kierownik urzędu stanu cywilnego wydaje zaświadczenie stwierdzające brak okoliczności wyłączających zawarcie małżeństwa oraz treść i datę złożonych przed nim oświadczeń w sprawie nazwisk przyszłych małżonków i ich dzieci, które ważne jest przez okres 6 miesięcy od jego wydania (art. $4^{1} \S 3$ k.r.o.). Treść tego za-

34 Należy zwrócić uwagę, że w art. 8 § 2 k.r.o. użyta jest liczba pojedyncza w odniesieniu do dokumentu, który duchowny ma przekazać do u.s.c. celem sporządzenia aktu małżeństwa zawartego w trybie art. $1 \S 2$ k.r.o. Natomiast w art. 91 p.a.s.c. polecającym ministrowi właściwemu do spraw wewnętrznych wydanie stosownych aktów wykonawczych ustawodawca używa liczby mnogiej. Stanowi bowiem, że podstawą sporządzenia aktu małżeństwa przez kierownika u.s.c. są przekazane do u.s.c. zaświadczenie o braku okoliczności wyłączających zawarcie małżeństwa oraz zaświadczenie o złożeniu przez strony oświadczeń o wstąpieniu w związek małżeński. Są to obecnie dwa fizycznie odrębne dokumenty na podstawie, których dokonuje się rejestracji stanu cywilnego.

35 Dz. U. Nr 36, poz. 180 z późn. zm. Przyjęte rozwiązanie jest słuszne, bowiem wymóg dokonania pouczenia osób zamierzających wstąpić w związek małżeński i tak był (i jest) realizowany przez kierownika u.s.c. na mocy art. $3 \S 3$ k.r.o., niezależnie od brzmienia nieobowiązującego już przepisu art. 62a p.a.s.c. Szerzej: Tunia 2006, 165-169; Mezglewski, Tunia 2007, 150-156.

36 Tunia 2015, 191. 
świadczenia obejmuje zatem stosowne zapewnienia stron dotyczące ich zdolności prawnej do zawarcia małżeństwa oraz oświadczenia dotyczące ich nazwisk oraz nazwisk dzieci zrodzonych z zamierzonego małżeństwa (art. 81 p.a.s.c.).

Przyjęcie zaświadczenia, o którym mowa w art. $4^{1} \S 1$ k.r.o dokonywane jest przez duchownego na etapie czynności poprzedzających zawarcie małżeństwa. Obowiązek ten wynika z art. $8 \S 1$ k.r.o., który stanowi, że „duchowny, przed którym zawierany jest związek małżeński podlegający prawu wewnętrznemu kościoła albo innego związku wyznaniowego, nie może przyjąć oświadczeń przewidzianych w art. $1 \S 2$ - bez uprzedniego przedstawienia mu zaświadczenia stwierdzającego brak okoliczności wyłączających zawarcie małżeństwa, sporządzonego przez kierownika urzędu stanu cywilnego". Brak tego zaświadczenia uniemożliwia duchownemu podjęcie dalszych czynności w procedurze zawierania małżeństwa w formie wyznaniowej. Przez „brak zaświadczenia” należy przy tym rozumieć sytuację fizycznego braku tego dokumentu (zaświadczenie w ogóle nie zostało doręczone duchownemu), jak też brak prawny, polegający na utracie ważności złożonego zaświadczenia w dniu zawarcia małżeństwa ${ }^{37}$.

Duchowny przyjmując zaświadczenie o braku okoliczności wyłączających zawarcie małżeństwa wykonuje - na tym etapie postępowania czynność zleconą z zakresu administracji stanu cywilnego, dla której upoważnienie ustawowe znajduje w art. $8 \S 2$ k.r.o. Wykonanie powyższego zadania przez duchownego polega nie tylko na przyjęciu zaświadczeń, ale również na odmowie przyjęcia oświadczeń woli jednoczesnego zawarcia małżeństwa podlegającego prawu polskiemu w sytuacji, gdy nupturienci nie przedłożyli zaświadczenia, o którym mowa w art. $4^{1} \S 1$ k.r.o. lub złożyli zaświadczenie, którego termin ważności upłynął. Obowiązek ten nie dotyczy sytuacji zawierania małżeństwa w trybie art. $9 \S 2$ k.r.o. ${ }^{38}$

37 Ostatni dzień jego ważności powinien być na nim jednoznacznie stwierdzony. Szerzej: Sobański 2003, 31; Smyczyński 2002, 167.

38 Zgodnie z tym przepisem w razie niebezpieczeństwa grożącego bezpośrednio życiu jednej ze stron, oświadczenia przewidziane w art. $1 \S 2$ k.r.o. mogą zostać złożone wobec duchownego bez przedstawiania mu zaświadczenia z u.s.c. stwierdzającego brak okoliczności wyłączających zawarcie małżeństwa. Strony jednak w takim wypadku mają obowiązek złożenia przed duchownym zapewnienia, że nie wiedzą o istnieniu między nimi takich okoliczności. 


\subsubsection{PRZYJĘCIE OŚWIADCZEŃ, O KTÓRYCH MOWA W ART. 1 § 2 K.R.O.}

Zadaniem duchownego jako podmiotu administrującego w procedurze zawierania małżeństwa cywilnego $\mathrm{w}$ formie wyznaniowej jest przyjęcie od stron oświadczeń woli jednoczesnego zawarcia małżeństwa podlegającego prawu polskiemu składanych przy zawieraniu małżeństwa wyznaniowego (art. $1 \S 2$ k.r.o.). Duchownym uprawnionym do wykonania tego zadania jest ten, który zajmuje jedno ze stanowisk uprawniających do przyjmowania oświadczeń o wstąpieniu w związek małżeński, wymienionych w części I. obwieszczenia Ministra Spraw Wewnętrznych z dnia 5 lutego 2015 r. ${ }^{39}$ Należy jednak podkreślić, że pozycja prawna tego duchownego określona została przez ustawodawcę polskiego w dwojaki sposób, bowiem duchowny jako podmiot urzędowy kompetentny do przyjęcia oświadczeń stron, o których mowa w art. $1 \S 2$ k.r.o., określony został również w przepisach ustaw indywidualnych związków wyznaniowych mających prawo do procedowania tej formy zawarcia małżeństwa cywilnego ${ }^{40}$. W jedenastu takich ustawach zawarto bowiem niemal identycznie brzmiące przepisy, stanowiące że „osobę duchowną, przed którą składa się oświadczenia o zawarciu małżeństwa określa prawo wewnętrzne danego kościoła albo innego związku wyznaniowego ${ }^{41}$.

39 Obwieszczenie Ministra Spraw Wewnętrznych z dnia 5 lutego 2015 r. w sprawie ogłoszenia wykazu stanowisk, których zajmowanie upoważnia do przyjmowania oświadczeń o wstąpieniu w związek małżeński oraz sporządzania zaświadczeń stanowiących podstawę sporządzenia aktu małżeństwa zawartego w sposób określony w art. 1 § 2 i 3 Kodeksu rodzinnego i opiekuńczego (M. P. z 2015 r., poz. 230).

40 Szerzej: Tunia 2016, 285-298; Tunia 2015, 196-198.

41 Są to następujące przepisy: art. 15a ustawy z dnia 17 maja 1989 r. o stosunku Państwa do Kościoła Katolickiego w Rzeczypospolitej Polskiej (tekst jedn. Dz. U. z 2013 r., poz. 1169 z późn. zm); art. 12a ustawy z dnia 4 lipca 1991 r. o stosunku Państwa do Polskiego Autokefalicznego Kościoła Prawosławnego (tekst jedn. Dz. U. z 2014 r., poz. 1726); art. 12a ustawy z dnia 13 maja 1994 r. o stosunku Państwa do Kościoła Ewangelicko-Augsburskiego w Rzeczypospolitej Polskiej (tekst jedn. Dz. U. z 2015 r., poz. 43); art. 8a ustawy z dnia 13 maja 1994 r. o stosunku Państwa do Kościoła Ewangelicko-Reformowanego w Rzeczypospolitej Polskiej (Dz. U. Nr 73, poz. 324 z późn. zm.); art. 11a ustawy z dnia 30 czerwca 1995 r. o stosunku Państwa do Kościoła Ewangelicko-Metodystycznego w Rzeczypospolitej Polskiej (tekst jedn. Dz. U. z 2014 r., poz. 1712); art. 10a ustawy z dnia 30 czerwca 1995 r. o stosunku Państwa do Kościoła Chrześcijan Baptystów w Rzeczpospolitej Polskiej 
Oświadczenia woli jednoczesnego zawarcia małżeństwa podlegającego prawu polskiemu winny zostać przyjęte przez duchownego w związku z zawieraniem małżeństwa wyznaniowego. Obowiązek ten wyraźnie wynika z art. 8 § 2 k.r.o. w związku z brzmieniem art. 1 § k.r.o. stanowiącym, że „małżeństwo zostaje również zawarte, gdy mężczyzna i kobieta zawierający związek małżeński podlegający prawu wewnętrznemu kościoła albo innego związku wyznaniowego w obecności duchownego oświadczą wolę jednoczesnego zawarcia małżeństwa podlegającego prawu polskiemu".

Duchowny wykonując powyższe zadanie pełni podobną rolę, jaką spełnia kierownik u.s.c. w przypadku zawierania małżeństwa w formie cywilnej (art. $1 \S 1$ k.r.o.), czy też konsul w sytuacji zawierania małżeństwa cywilnego przez obywateli polskich przebywających za granicą (art. $1 \S 4$ k.r.o.). W doktrynie podkreśla się jednak, że powierzenie duchownemu zadań publicznych, które należą do kierownika u.s.c. nie powoduje, że duchowny ten występuje w charakterze tego urzędnika ${ }^{42}$. Duchowny bierze jedynie udział w czynnościach o charterze publicznoprawnym, sprawując w tym zakresie funkcje organu publicznego zleconą mu przez prawo państwowe ${ }^{43}$.

\subsubsection{SPORZĄDZENIE ZAŚWIADCZENIA O ZAWARTYM MAŁŻEŃSTWIE}

Obowiązek sporządzenia przez duchownego zaświadczenia o zawartym małżeństwie wynika $\mathrm{z}$ art. $8 \S 2$ k.r.o. Podmiotem tego obowiązku jest

(tekst jedn. Dz. U. z 2015 r., poz. 169); art. 10a ustawy z dnia 30 czerwca 1995 r. o stosunku Państwa do Kościoła Adwentystów Dnia Siódmego w Rzeczypospolitej Polskiej (tekst jedn. Dz. U. z 2014 r., poz. 1889); art. 9a ustawy z dnia 30 czerwca 1995 r. o stosunku Państwa do Kościoła Polskokatolickiego w Rzeczypospolitej Polskiej (tekst jedn. Dz. U. z 2014 r., poz. 1599); art. 9a ustawy z dnia 20 lutego 1997 r. o stosunku Państwa do gmin wyznaniowych żydowskich w Rzeczypospolitej Polskiej (tekst jedn. Dz. U. z 2014 r., poz. 1798); art. 8a ustawy z dnia 20 lutego 1997 r. o stosunku Państwa do Kościoła Starokatolickiego Mariawitów w Rzeczypospolitej Polskiej (tekst jedn. Dz. U. z 2015 r., poz. 14); art. 11a ustawy z dnia 20 lutego 1997 r. o stosunku Państwa do Kościoła Zielonoświątkowego w Rzeczypospolitej Polskiej (tekst jedn. Dz. U. z 2015 r., poz. 13).

42 Góralski 2007, 3-4.

43 Tunia 2008, 36. 
osoba wymieniona w wykazie stanowisk MSW z dnia 5 lutego 2015 r., których zajmowanie upoważnia do sporządzenia zaświadczenia stanowiącego podstawę sporządzenia aktu małżeństwa zawartego w sposób określony w art. $1 \S 2$ i 3 k.r.o. Obowiązek duchownego polega - w istocie - na stwierdzeniu $\mathrm{w}$ treści zaświadczenia dwóch zdarzeń prawnych, tj.:

- złożenia przez strony oświadczeń, o których mowa w art. $1 \S 2$ k.r.o., oraz

- zawarcia małżeństwa podlegającego prawu wewnętrznemu danego kościoła albo innego związku wyznaniowego (zob. art. $8 \S 2$ k.r.o. $)^{44}$.

W praktyce obowiązek duchownego sprowadza się do wypełnienia odpowiednich rubryk urzędowego formularza tego zaświadczenia, odebrania na nim podpisów stron oraz świadków, oraz złożenia podpisu przez duchownego kompetentnego do przyjęcia oświadczeń stron o wstąpieniu w związek małżeński oraz podpisu duchownego upoważnionego do jego sporządzenia - stosownie do wytycznych określonych w części II. obwieszczenia Ministra Spraw Wewnętrznych z 5 lutego 2015 r. w sprawie podmiotów kompetentnych do dokonywania tych czynności. Poprawne sporządzenie zaświadczenia o zawartym małżeństwie teoretycznie może zatem wymagać współdziałania dwóch różnych duchownych ${ }^{45}$, z których jeden obowiązany jest poświadczyć swym podpisem fakt złożenia wobec niego przez strony oświadczeń woli, o których mowa w art. $1 \S 2$ k.r.o., zaś drugi poświadczyć swym podpisem autentyczność danych zawartych w zaświadczeniu, nadając mu charakteru dokumentu urzędowego.

\subsubsection{PRZEKAZANIE ZAŚWIADCZENIA O ZAWARTYM MAŁŻEŃSTWIE DO U.S.C.}

Przekazanie do urzędu stanu cywilnego zaświadczenia stanowiącego podstawę rejestracji małżeństwa zawieranego na podstawie art. $1 \S 2$ k.r.o. jest ostatnim obowiązkiem duchownego w procedurze zawierania małżeństwa $\mathrm{w}$ formie wyznaniowej. Podstawę prawną do wykonania tego zadania znajdujemy w art. $8 \S 3$ k.r.o., zgodnie z którym duchowny ma spełnić ten obowiązek w terminie 5 dni od zawarcia małżeństwa. Treść art. $8 \S 3$ k.r.o.

\footnotetext{
44 Tunia 2015, 192.

45 Por. Zieliński 2011, 19-33.
} 
pozwala domniemywać, iż obowiązek ten nałożony został na duchownego uprawnionego do sporządzenia przedmiotowego zaświadczenia. Rozwiązanie to należy uznać za zasadne. Duchownymi, o których mowa, są bowiem osoby spełniające najczęściej funkcje administracyjne w podstawowych, terytorialnych jednostkach organizacyjnych poszczególnych kościołów i innych związków wyznaniowych (parafii). W praktyce z reguły osobą przekazującą zaświadczenie jest proboszcz (administrator) parafii ${ }^{46}$.

Oceniając zaś charakter czynności przekazania zaświadczenia do urzędu stanu cywilnego stwierdzić trzeba, iż jest to jedynie czynność porządkowa, nie czynność prawna ${ }^{47}$. Zadanie to realizowane przez duchownego ma jednak charakter publiczny. Czynione jest ono w interesie stron tego postępowania (małżonków) i wobec organu administracji publicznej, którym jest kierownik u.s.c. ${ }^{48}$

\subsection{ZADANIA W SYTUACJACH NADZWYCZAJNYCH}

W przypadku zawierania małżeństwa w trybie określonym art. $9 \S 2$ k.r.o., tj. w razie niebezpieczeństwa grożącego bezpośrednio życiu jednej ze stron, zakres zadań publicznych wykonywanych przez duchownego jest szerszy. Obowiązany jest on bowiem spełnić wszystkie powinności, jakie ustawodawca nakłada na niego w trybie zwyczajnym, a ponadto - zgodnie z poleceniem zawartym w art. 9 § 2 k.r.o. - winien przyjąć od nupturientów zapewnienia, że nie wiedzą oni o istnieniu okoliczności wyłączających zawarcie małżeństwa. Realizacja tego wymogu nastręcza jednak pewne trudności praktyczne, bowiem ustawodawca nie uregulował kwestii ,pobrania” przez duchownego formularzy „zaświadczenia o braku okoliczności wyłączających zawarcie małżeństwa zawartego w sposób określony w art. $1 \S 2$ i 3 k.r.o.” oraz formularza ,zaświadczenia stanowiącego podstawę sporządzenia aktu małżeństwa" na wypadek zajścia sytuacji zawierania małżeństwa in periculo mortis. Henryk Chwyć, wieloletni kierownik u.s.c. w Lublinie, proponuje aby w takim wypadku duchowny przekazał do

46 Zob. Mezglewski, Tunia 2007, 174.

47 Duchowny nie jest bowiem wnioskodawcą w sprawie o rejestrację małżeństwa. Są nimi sami małżonkowie.

48 Zob. Tunia 2008, 39. 
urzędu stanu cywilnego zamiast zaświadczenia o zawartym małżeństwie odpis aktu małżeństwa sporządzonego w księdze kościelnej ${ }^{49}$.

Problem jednak jest istotny, ponieważ realizacja obowiązku przyjęcia przez duchownego zapewnień stron wymaga uzyskania od nich nie tylko oświadczenia wiedzy o nieistnieniu między nimi przeszkód, o których mowa $\mathrm{w}$ art. 10-15 k.r.o., co wynika z brzmienia art. 9 § 2 k.r.o., ale również innych danych, które zgodnie z przepisami nowej ustawy - Prawo o aktach stanu cywilnego - składają się na treść tych zapewnień. W porównaniu bowiem z dotychczasową regulacją treść tego zapewnienia została znacznie rozbudowana. W literaturze przedmiotu podnosi się wręcz, iż rozbudowano ją nadmiernie ${ }^{50}$. Art. 76 ust. 4 p.a.s.c przewiduje bowiem, że zapewnienia te obejmują poza oświadczeniami o braku przeszkód małżeńskich (ust. 4 pkt 6), oświadczenia o wyborze nazwiska (nazwisk), które będą nosiły osoby zamierzające zawrzeć małżeństwo po jego zawarciu, oraz oświadczenia o nazwisku dzieci zrodzonych z tego małżeństwa (ust. 4 pkt 5), a także oświadczenia o nazwiskach, imionach oraz nazwiskach rodowych rodziców każdej z osób zamierzających zawrzeć małżeństwo (ust. 4 pkt 4). Oświadczenia te nupturienci składają pod rygorem odpowiedzialności karnej za składanie fałszywych oświadczeń. Poza powyższymi oświadczeniami - w treści zapewnienia - ustawodawca wymaga podania innych informacji. Są to informacje dotyczące: nazwisk i imion osób zamierzających zawrzeć małżeństwo, ich nazwisk rodowych, jeżeli można je ustalić, stanu cywilnego, obywatelstwa, daty i miejsca urodzenia, numeru PESEL, jeżeli zostały nadane, oraz oznaczenia przedstawionych dokumentów tożsamości (ust. 4 pkt 1), wskazania miejsca zawarcia małżeństwa, jeżeli osoba zamierzająca zawrzeć małżeństwo pozostawała uprzednio w związku małżeńskim albo prawomocnie stwierdzono nieistnienie małżeństwa (ust. 4 pkt 2), wskazania wspólnych dzieci osób zamierzających zawrzeć małżeństwo oraz oznaczenia ich aktów urodzenia i urzędu stanu cywilnego, w którym zostały sporządzone, jeżeli są znane (ust. 4 pkt 3) ) $^{51}$.

49 Chwyć 1999, 27.

50 Basior, Czajkowska, Sorbian 2015, 152-153.

51 W literaturze podnosi się, że nie wiadomo czemu ma służyć np. wskazanie miejsca zawarcia poprzedniego małżeństwa (pkt 2 ust. 4), jak też podanie informacji o wspólnych dzieciach (pkt 3 ust. 4). Nie mają bowiem one związku z istotą zapewnienia określoną w art. $4^{1}$ k.r.o. Zob. Basior, Czajkowska, Sorbian 2015, 153. 
Duchowny obowiązany jest zatem przyjąć nie tylko oświadczenia o nieistnieniu przeszkód małżeńskich, ale również oświadczenia o wyborze nazwiska dla przyszłych małżonków i ich dzieci, jak też oświadczenia o imionach i nazwiskach rodziców stron. Uznać zaś należy, że duchowny nie jest obowiązany - w przypadku zawierania małżeństwa w sytuacji nadzwyczajnej - do uzyskania od nupturientów innych informacji składających się na treść zaświadczenia wydawanego przez kierownika u.s.c., o których mowa w ust. 4 art. 76 p.a.s.c., zważywszy, iż art. $4^{1} \S 1$ k.r.o. określający istotę treści zapewnień takich danych nie przewiduje.

\section{PODSUMOWANIE}

Charakter i katalog zadań wykonywanych przez duchownych działających jako podmioty administrujące w sprawach z zakresu administracji stanu cywilnego wiąże się stricte z czynnościami (prawami i obowiązkami), jakie ustawodawca polski nałożył na podmioty wyznaniowe w związku z zawarciem i rejestracją małżeństwa powstającego na podstawie art. 1 $\S 2$ k.r.o. Funkcje, jakie w toku procedury zawarcia małżeństwa w tym trybie sprawuje duchowny mają charakter zadań zleconych z zakresu administracji publicznej. Podstawę do ich wykonania stanowią odpowiednie przepisy prawa państwowego (k.r.o., p.a.s.c.). Do czynności, które wykazują charakter zadań zleconych z zakresu administracji publicznej zaliczyć tu możemy: przyjęcie oświadczeń woli o zawarciu małżeństwa wyznaniowego oraz jednoczesnego zawarcia małżeństwa podlegającego prawu polskiemu (art. $1 \S 2$ k.r.o.), sporządzenie i przekazanie zaświadczenia o zawartym małżeństwie do urzędu stanu cywilnego (art. $8 \S 2$ i 3 k.r.o.). W toku tych czynności duchowny działa nie we własnym imieniu, ale jako organ osoby prawnej, którą jest określona jednostka organizacyjna kościoła lub innego związku wyznaniowego (np. parafia). Wykonując zlecone mu zadania $\mathrm{z}$ zakresu administracji stanu cywilnego duchowny staje się funkcjonariuszem publicznym w znaczeniu funkcjonalnym. Jest podmiotem administrującym, który realizuje tę funkcję w imieniu kościoła lub innego związku wyznaniowego uprawnionego do stosowania wyznaniowej formy zawarcia małżeństwa na podstawie odpowiednich przepisów prawa. 


\section{BIBLIOGRAFIA}

Basior, Iwona, Alicja Czajkowska, Danuta Sorbian. 2015. Prawo o aktach stanu cywilnego z komentarzem. Przepisy wykonawcze i zwiazkowe oraz wzory dokumentów. Warszawa: Lex a Wolters Kluwer business.

Biernat, Stanisław. 1993. „Prywatyzacja zadań publicznych (zarys problematyki)”. Państwo i Prawo 5: 6-27.

Boć, Jan. 1998. „Organizacja prawna administracji”. W: Prawo administracyjne, red. Jan Boć. Wrocław: Wydawnictwo Kolonia Limited.

Boć, Jan. 2005. „Podmioty prywatne wykonujące funkcje administracji publicznej". W: Prawo administracyjne, red. Jan Boć, 175-185. Wrocław: Wydawnictwo Kolonia Limited.

Chwyć, Henryk. 1999. Zawarcie malżeństwa i jego rejestracja w prawie polskim. Poradnik dla kierowników Urzędu Stanu Cywilnego. Lublin: Wydawnictwo Stowarzyszenia Urzędników Stanu Cywilnego.

Czajkowska, Alicja, Elżbieta Pachniewska. 2005. Prawo o aktach stanu cywilnego. Komentarz. Orzecznictwo. Wzory dokumentów i pism. Warszawa: Wydawnictwo Lexis Nexis.

Garlicki Leszek, Marek Zubik, Marta Derlatka, Kazimierz Działocha, Paweł Sarnecki, Janusz Sokolewicz, Wojciech Trzciński i Marcin Wiącek. 2016. Konstytucja Rzeczypospolitej Polskiej. Komentarz. Tom I. Warszawa: Wydawnictwo Sejmowe. Lex nr 531978.

Góralski, Wojciech. 2005. „Czynności i rola duchownego przy zawieraniu małżeństwa «konkordatowego»". W: Prawo rodzinne w Polsce $i$ w Europie. Zagadnienia wybrane, red. Piotr Kasprzyk. Lublin: Towarzystwo Naukowe KUL.

Góralski, Wojciech. 2007. „Funkcje publiczne duchownego przy zawieraniu małżeństwa konkordatowego". W: Funkcje publiczne zwiąków wyznaniowych. Materiały III Ogólnopolskiego Sympozjum Prawa Wyznaniowego (Kazimierz Dolny, 16-18 maja 2006), red. Artur Mezglewski. Lublin: Wydawnictwo KUL.

Mezglewski, Artur, Anna Tunia. 2007. Wyznaniowa forma zawarcia matżeństwa cywilnego. Warszawa; Wydawnictwo C.H. Beck.

Osuchowska, Marta. 2010. „Świadek kwalifikowany - duchowny obecny przy zawieraniu małżeństwa wyznaniowego ze skutkami cywilnymi w świetle przepisów wewnętrznych Kościołów i związków wyznaniowych oraz przepisów prawa polskiego". W: Prawo państwowe a prawo wewnętrzne zwiazków wyznaniowych. Pamiętnik VII Zjazdu Katedr i Wykładowców Prawa Wyznaniowego, Gniezno 11-12 IX 2010, red. Krzysztof Krasowski, Małgorzata Materniak-Pawłowska, Maksymilian Stanulewicz. Poznań: Wydawnictwo Ars boni et aequi. 
Rakoczy, Bartosz. 2014. „Proboszcz jako funkcjonariusz publiczny według prawa polskiego". W: Kościoły i inne związki wyznaniowe w stużbie dobru wspólne$m u$, red. Wacław Uruszczak, Katarzyna Krzysztofek, Maciej Mikuła. Kraków: Wydawnictwo UJ.

Skrzydło, Wiesław. 2013. Konstytucja Rzeczypospolitej Polskiej. Komentarz. Lex nr 428263.

Smyczyński, Tadeusz. 2002. „Odpowiedzialność odszkodowawcza duchownego z powodu naruszenia prawa przy zawieraniu małżeństwa”. Ruch Prawniczy Ekonomiczny i Socjologiczny 2: 165-177.

Sobański, Remigiusz. 2003. „Zaświadczenie urzędu stanu cywilnego a przesłanki małżeństwa «konkordatowego»". Państwo i Prawo 5: 30-33.

Stanisz, Piotr. 2007. Porozumienia w sprawie regulacji stosunków między państwem i niekatolickimi zwiąkami wyznaniowymi we włoskim porzadku prawnym. Lublin: Wydawnictwo KUL.

Szadok-Bratuń, Aleksandra. 2012. „Instytucja zawarcia małżeństwa «konkordatowego» przykładem nietypowej prywatyzacji zadań publicznych". W: Prawne aspekty prywatyzacji, red. Jolanta Blicharz. Wrocław: Biblioteka Cyfrowa.

Tunia, Anna. 2006. „Obowiązki duchownego w procedurze zawierania małżeństwa wyznaniowego ze skutkami cywilnymi”. Studia z Prawa Wyznaniowego 9: $155-179$.

Tunia, Anna. 2008. „Wykonywanie funkcji publicznych przez duchownego w procedurze zawierania małżeństwa cywilnego w formie wyznaniowej”. Przegląd Prawno-Ekonomiczny 2(1): 33-39.

Tunia, Anna. 2015. Recepcja prawa wewnętrznego związów wyznaniowych w prawie polskim. Lublin: Wydawnictwo KUL.

Tunia, Anna. 2016. „Podmioty urzędowe procedujące przy zawieraniu małżeństw cywilnych $\mathrm{w}$ formie wyznaniowej w przypadku nupturientów pozbawionych wolności”. W: Wolność sumienia i religii osób pozbawionych wolności. Aspekty prawne i praktyczne, red. Jerzy Nikołajew, Konrad Walczuk. Warszawa: Wydawnictwo Unitas.

Wrzosek, Stanisław. 2013. „Podmiot administrujący”. W: Leksykon administratywisty, red. Stanisław Wrzosek, Anna Haładyj, Michał Domagała. Radom: Wydawnictwo Wyższej Szkoły Handlowej w Radomiu.

Zieliński, Tadeusz J. 2011. „Stosowanie wyznaniowej formy zawarcia małżeństwa cywilnego poza Kościołem katolickim”. Państwo i Prawo 2: 19-33. 


\section{THE RELIGIOUS MINISTER AS AN ADMINISTRATIVE ENTITY IN CASES CONCERNING CIVIL STATUS ADMINISTRATION}

Summary

The aim of the article is to present the character and variety of tasks performed by entities belonging to churches and other religious organizations as far as civil status administration is concerned. In the first part, the key terms used in the article, such as civil status administration and administrative entity, are introduced and explained. Then the administrative entities involved in the system of civil status administration are enumerated, which is followed by the analysis of the tasks realized by religious entities (religious minister) as subjects engaged in the administration of civil status. These tasks concern activities connected with concluding and registering marriages in accordance with Art. $1 \S 2$ of the Family and Guardianship Code. They are carried out under ordinary as well as extraordinary circumstances, that is, in cases of direct life threat to one of the parties concluding a marriage.

The article concludes by arguing that that the functions performed by the religious minister in the course of the procedure of concluding a marriage in accordance with Art. $1 \S 2$ of the Family and Guardianship Code have the character of administrative tasks delegated to public administration. The basis for their execution of these functions are appropriate regulations of state law. When performing these activities, the religious minister does not act on his behalf but as a body of a legal entity which is a particular organizational unit of a church or some other religious organization (e.g., a parish). Thus, the religious minister is an administering entity who carries out this function on behalf of a church or some other religious organization entitled to apply the religious form of concluding a marriage in accordance with relevant legal regulations.

Key words: public administration; civil status administration; administrative entity; marriage; religious minister; churches and religious organizations 